J. Bangladesh Acad. Sci., Vol. 42, No. 1, 41-54, 2018

\title{
HYDROGEOLOGICAL CLASSIFICATION AND THE CORRELATION OF GROUNDWATER CHEMISTRY WITH BASIN FLOW IN THE SOUTH-WESTERN PART OF BANGLADESH
}

\author{
SHAHPARA SHEIKH DOLA*, KHAIRUL BAHSAR, MAZEDA ISLAM AND \\ MD. MIZANUR RAHMAN SARKER \\ Department of Geological Sciences, Jahangirnagar University, Savar, Dhaka, Bangladesh
}

\begin{abstract}
Attempt has been made to find the relationship between the basin groundwater flow and the current water chemistry of south-western part of Bangladesh considering their lithological distribution and aquifer condition. The correlation of water chemistry and basin groundwater flow is depicted in the conceptual model. The water-types of shallow groundwater are predominantly $\mathrm{Mg}-\mathrm{Na}-\mathrm{HCO}_{3}$ and $\mathrm{Ca}-$ $\mathrm{Mg}-\mathrm{Na}-\mathrm{HCO}_{3}$ type. In the deep aquifer of upper delta plain is predominately $\mathrm{Na}-\mathrm{Cl}, \mathrm{Ca}-\mathrm{HCO}_{3}$ and $\mathrm{Mg}-$ $\mathrm{HCO}_{3}$ type. In the lower delta plain $\mathrm{Na}-\mathrm{Cl}$ type of water mainly occurs in the shallow aquifer and occasionally $\mathrm{Ca}-\mathrm{HCO}_{3}, \mathrm{Ca}-\mathrm{Mg}-\mathrm{Na}-\mathrm{HCO}_{3}$ and $\mathrm{Mg}-\mathrm{HCO}_{3}$ type may also occur in shallow aquifer of the eastern part of lower delta plain which could have originated from the recent recharge of rain water. Na$\mathrm{Cl}$ type water is also found in the deep aquifer of lower delta plain. The origin of $\mathrm{Na}-\mathrm{Cl}$ type water in the deep aquifer of lower delta part might be connate water or present day sea water intrusion. Fresh water occurring in the deep aquifer in the lower delta area is mostly of $\mathrm{Mg}-\mathrm{Ca}-\mathrm{HCO}_{3}$ and $\mathrm{Na}-\mathrm{HClO}_{3}$ types. This type of water originate from intermediate or deep basin flow from the northern part of Bangladesh. The probable source of deep groundwater is Holocene marine transgression (Khan et al. 2000) occurred in 3000-7000 cal years BP and the deep groundwater of Upper Delta plain and Lower Delta plain is clearly influenced by deep basin flow coming from north part of Bangladesh.
\end{abstract}

Key words: Ganges delta, basin groundwater flow, groundwater chemistry, hydrogeology, water type

\section{INTRODUCTION}

The study area is in the south-western part of Bangladesh and consists of 21 districts (Fig. 1), which is the part of the Ganges Brahmaputra Delta. In the north and east the area is bounded by the river Ganges and Meghna, in the west by Indian border. It

covers 21 districts named as Kushtia, Meherpur, Chuadanga, Jhenaidah, Magura, Rajbari, Faridpur, Narail, Jessore, Gopalgonj, Madaripur, Shariatpur, Satkhira, Khulna, Bagerhat, Pirojpur, Potuakhali, Jhalakathi, Barisal and Bhola. The Ganges

* Corresponding author:<shahpara001@gmail.com>. 
delta is formed by the confluence of the Ganges (local name Padma), Brahmaputra (Jamuna), and Meghna rivers and their respective tributaries. The Ganges unites with the Jamuna (main channel of the Brahmaputra) and later joins the Meghna, finally flowing into the Bay of Bengal (http://en.wikipedia.org/wiki). The Ganges Delta and its surroundings is one of the largest alluvial plains in the world. It faces the Bay of Bengal and rivers flowing in the low land take their source from the Himalayan mountains. The deposition of sediments was vastly controlled by Quaternary sea level fluctuation, climatic conditions and tectonic activities (Umitsu 1987). The Bengal Basin was filled with sediments of Tertiary and Quaternary age (Morgan and McIntire1959; Umitsu 1985, 1987, 1993). Mainly the Ganges deltaic deposits of Late Holocene to Recent age cover the study area. The modern deltaic plain in the western Bengal Basin can be divided into two regions: the Upper Delta plain of meander belts of the GangesBhagirathi rivers in the north; and the lower delta plain with numerous tidal creeks in the south (Das et. al. 1996). The lower deltaic plain, formed in Pleistocene-Holocene time, is characterized by the presence of an extensive clay layer of varying thickness (15-76 m) which is underlain by silt, sand, and gravel (Deshmukh and Goswami 1973).

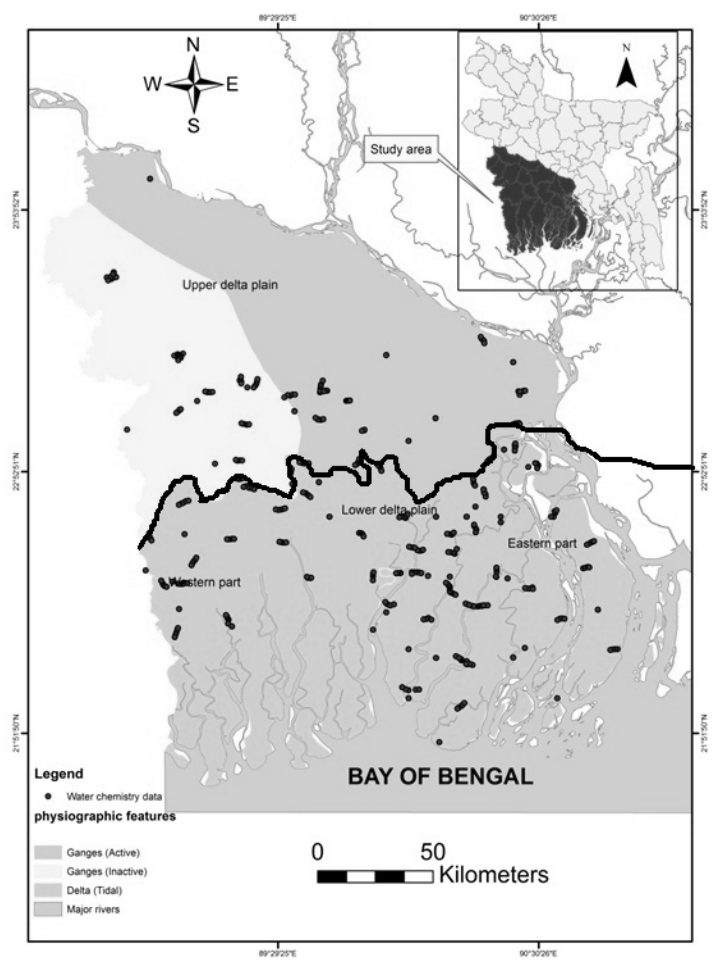

Fig. 1. Map of the study area with physiographic features and water chemistry data location (the dark line indicates the boundary of upper delta plain which is located above the line and lower delta plain which is located under the line). 
Studies of the Pleistocene to Holocene transition in the Bengal Basin (Umitsu 1987, 1993; Goodbred and Kuehl 2000a) have shown that an enormous Early Holocene sediment discharge by the GangesBrahmaputra (Goodbred and Kuehl 2000a) led to formation of a deltaic silt deposit up to $60 \mathrm{~m}$ thick over the oxidized lowstand surface beginning at about 10,000-11,000 cal years BP. Basin infilling was relatively complex following deposition of this unit due to migration and avulsion of the Ganges and Brahmaputra channels. Several studies (Banerjee and Sen 1988; Umitsu 1993; Goodbred and Kuehl 2000) suggest that maximum transgression was reached around $300 \mathrm{~km}$ about 7000 cal years BP in the western basin, including the Sunderbans and Kuakata area, and was followed by delta plain progradation. Ganges Brahmaputra Delta is classified as tide dominated delta (Khan and Islam 2008; Umitsu 1993). From the hydro stratigraphy of south-western Bangladesh up to the depth of $347 \mathrm{~m}$ is found as a complex sequence comprising mostly of sand, clay, silty-clay with occasional gravel beds. The source of the sediments deposited in this part of Bangladesh is the Northern Himalayan Range.

Main objectives of this work is to find out the correlation of groundwater chemistry and the basin flow, probable origin of water and their distinct influences controlling the major water type. Hydro-stratigraphic crosssections have been made to find out the aquifers geometry, and groundwater chemistry has been used to find their probable source and origin of water.

\section{METHODOLOGY}

The hydrogeological and hydro-geochemical investigation of the study area is made to analyze bore logs which include making hydro stratigraphic cross-sections, panel diagrams and 3D models using Rockworks15 ${ }^{\circledR}$ software. All data (bore log data, water chemistry data) were collected from Bangladesh Water development Board (BWDB) (2013) and the Department of Public Health Engineering (DPHE) (2010). About 2185 bore logs data were classified into upper delta plain and lower delta plain. Aquifer geometry and number of aquifers were delineated from hydrostratigraphic cross-section. Determination of the water type was based on about 795 water chemistry data using Piper diagram with the help of Aquachem $4{ }^{\circledR}$ software. Chemical facies of water has been identified based on chemistry and water type data. A conceptual flow model was developed and found the correlation of the distribution of chemical facies of water. Conceptual flow model has been prepared using Arc GIS 10.1 software.

\section{GEOLOGICAL SETTING OF THE STUDY AREA}

The Ganges Delta, one of the largest deltas in the world, is located in the lower reaches of the Ganges and the Brahmaputra (https://en.wikipedia.org/wiki/Brahmaputra_ River). Some important studies have been done of the landforms and Late Quaternary geology of this area (Umitsu 1993). The Ganges delta lies at the junction of three tectonic plates: the Indian plate, the Eurasian plate, and the Burma plate(http://en. wikipedia. org/wiki). The rivers Ganges and Brahmaputra flow into the delta from the northwest and the north. The landforms of 
the Bengal lowland, including the Ganges delta and its surrounding region, consist of Pleistocene uplands and alluvial lowlands. The relative height of the Pleistocene upland above the surface of the alluvial lowland is $3-10 \mathrm{~m}$ in the north and $0-5 \mathrm{~m}$ in the south (Umitsu 1993). The alluvial lowlands are subdivided into three geomorphological regions, namely the Brahmaputra- Jamuna floodplain in the north, the Sylhet basin in the northeast, and the Ganges Delta in the south of the region (Umitsu 1985). Mainly the Ganges deltaic deposits of Late Holocene to Recent age cover the study area. The surface lithology of the area is of deltaic deposits which are composed of tidal deltaic deposits, deltaic silt deposits and mangrove swamp deposits (Alam 1990). The subsurface lithology is characterized by a heterogeneous mixture of sand, silt and clay.

The Latest Pleistocene and Holocene sediments in the Ganges Delta and its surrounding region are divided into five units: the lowest, lower, middle, upper and uppermost units (Umitsu 1993). They have been deposited since the maximum epoch of the Last glacial age. The Ganges Brahmaputra Delta is classified as tide dominated delta as the system is characterized by its wide river mouths that has a pronounced upstream taper and welldeveloped channel bars and islands and is subjected to mesotidal to macrotidal conditions with spring tidal ranges typically $\geq 3 \mathrm{~m}$ (Goodbred and Saito 2012).

The study area constitutes the sub-aerial part of the Ganges-Brahmaputra delta. It can be typically subdivided into higher elevation; freshwater wetlands of the Upper Delta plain which graded sea-ward with a lower elevation saline Lower Delta plain occupied by saltmarsh and/or mangroves (Wright 1985). The Upper Delta plain lies in the northern side of the study area and is dominated by fluvial processes. The landward boundary of the Upper Delta plain is defined by the initiation of distributary development along the Ganges and the downstream edge is demarcated by the inland dry-season extent of saline water, typically encompassing land $>3 \mathrm{~m}$ above sea level. In general, shallow sub-surface stratigraphy of the upper delta plain consists of a fining upward succession starting with coarse channel sand deposits (3-20m thick) capped by thin floodplain muds (0.5-3 m). The lower delta plain can be defined as the subaerial delta inland to the limit of saline penetration during periods of low river discharge which is a zone up to $100 \mathrm{~km}$ wide that increases only minimally in elevation inland (elevations are typically $<3 \mathrm{~m}$ above mean sea level at the northern limit of salt-water intrusion) (Kuehl and Goodbred 2005). Hydro-stratigraphically, the Lower Delta plain can be further subdivided into Western Lower Delta plain (Satkhira, Khulna and Bagerhat Districts) and Eastern Lower Delta plain (Barisal Division). Western Lower Delta plain is underlain predominantly by thick clay and silty-clay aquitards (or aquiclude) up to $300 \mathrm{~m}$ depth.

\section{HYDRO-STRATIGRAPHY OF THE STUDY AREA}

There are 21 districts in the study area. In total 2185 bore log data of the study area were collected from published report of Bangladesh Water development Board (BWDB) and Department of Public Health Engineering (DPHE). The depth of these boreholes varied from 16 to $347 \mathrm{~m}$ (Fig. 2). 


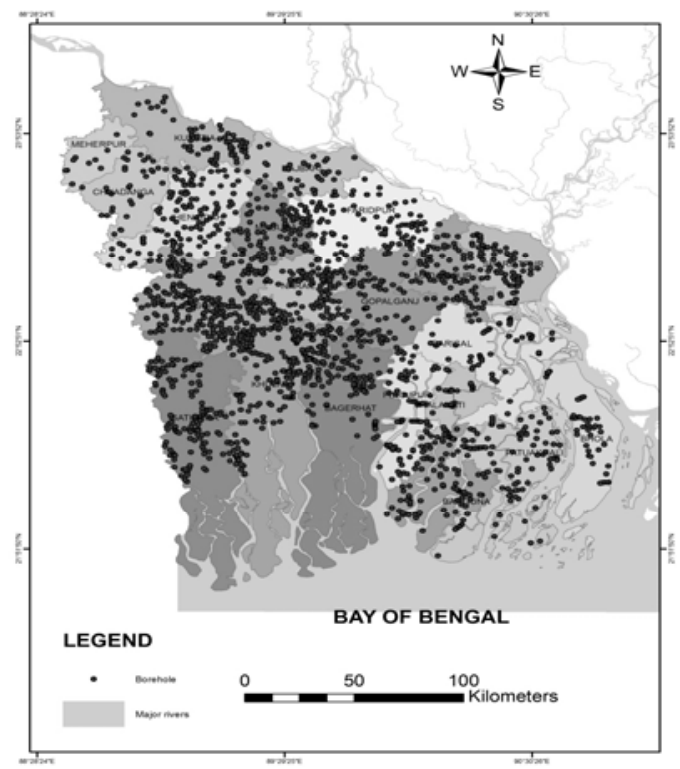

Fig. 2. Map of the study area with borehole data location.

The study area consists mostly of silty-clay layered aquitard and medium to coarse sandy gravel rich aquifer. From cross-section (Fig. 3 and Fig. 4) it is seen that upper delta plain has one definite aquifer which can be divided into shallow aquifer and deep aquifer. On the other hand, lower delta plain has more or less 3 aquifers. These can be divided in shallow and deep aquifer as well. The depth of shallow aquifer is considered up to $100 \mathrm{~m}$ and the depth of deep aquifer ranges from $120 \mathrm{~m}$ to $350 \mathrm{~m}$. The shallow and deep aquifers are connected in upper delta plain but in lower delta plain they are not connected and for

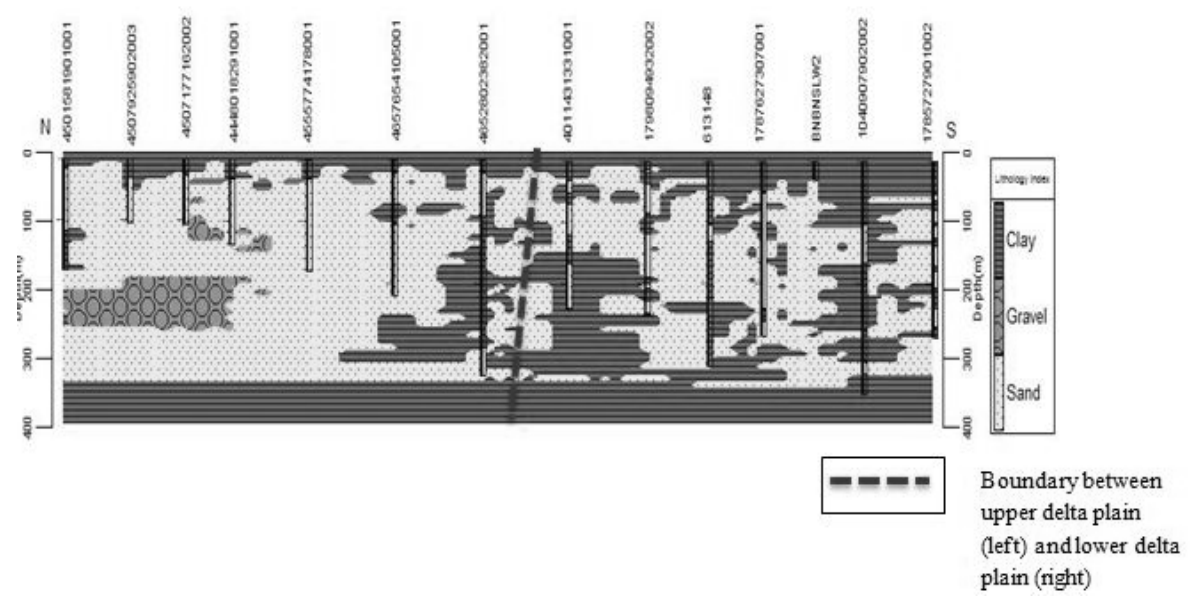

Fig. 3. Hydro stratigraphic cross-section across Kushtia, Jhenaidah, Magura, Narail, Khulna, Bagerhat, Pirojpur, Jhalakati, Potuakhali, Barguna and Potuakhali respectively. 
this reason, 3 or more aquifers can be identified in lower delta plain (Fig. 5).
Aquifer and aquitard are clearly visible in upper delta plain but irregular aquitard can

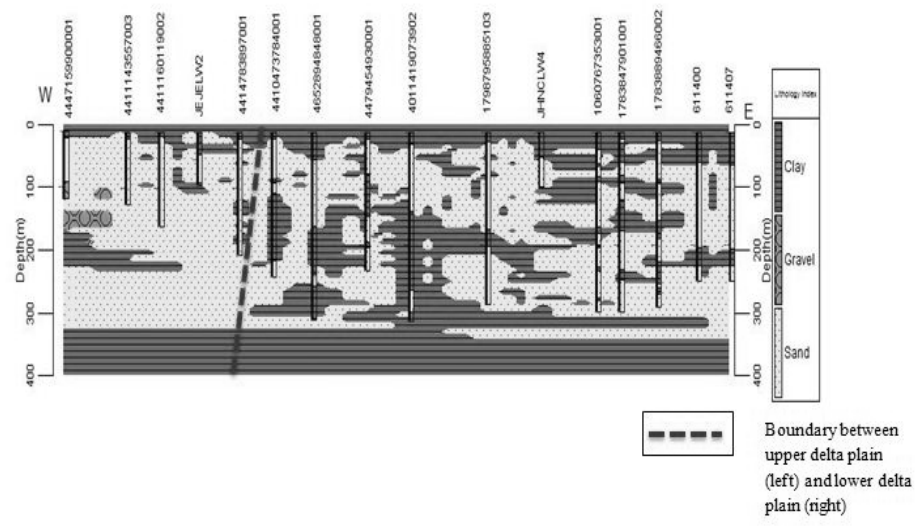

Fig. 4. Hydro stratigraphic cross-section across Jhenaidah, Jessore, Narail, Khulna, Bagerhat, Pirojpur, Jhalakati, Potuakhali, and Bhola respectively.

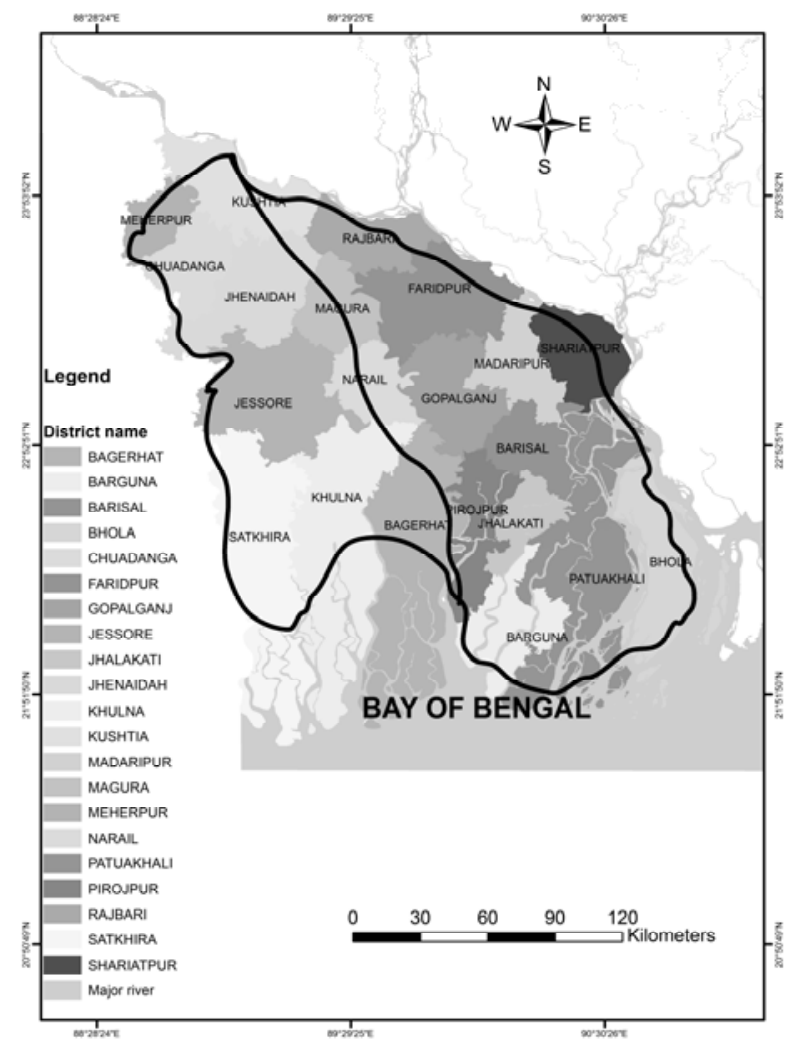

Fig. 5. Map showing panel diagram boundary of upper delta plain and lower delta plain. 
be seen in lower delta plain. Clay content is slightly higher in the western lower delta plain relative to eastern lower delta plain. mixing. This groundwater-surface water interaction is found by observing the different water types found in different depths.

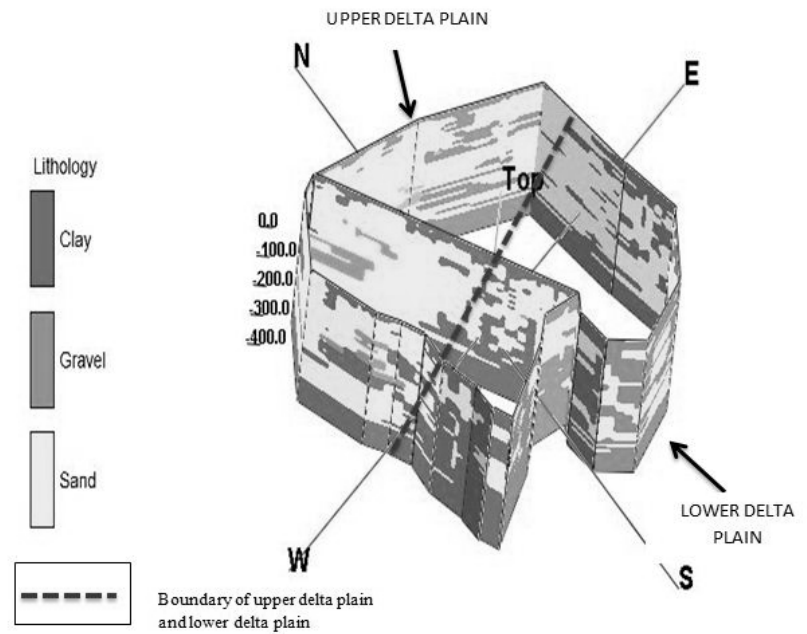

Fig. 6. Panel diagram of upper delta plain and lower delta plain.

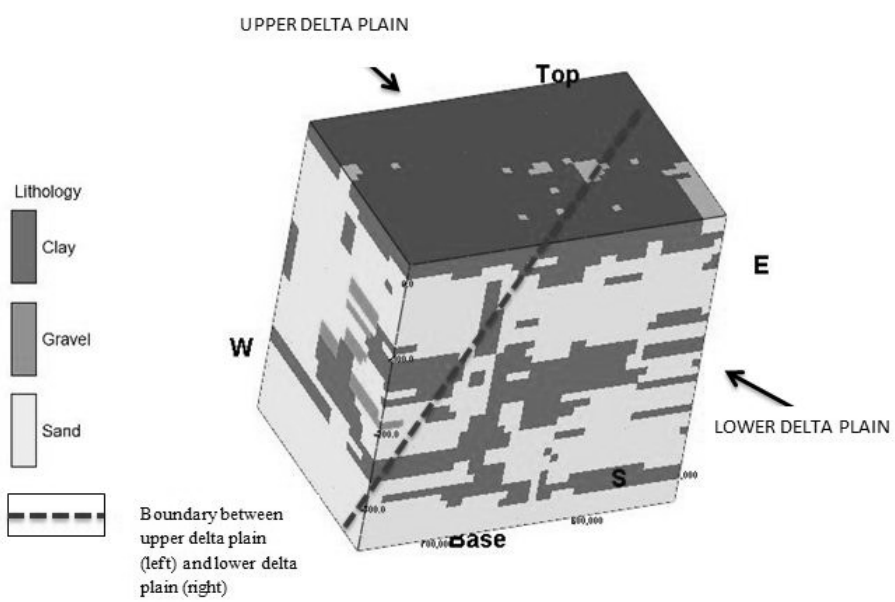

Fig. 7. 3D view of upper delta plain and lower delta plain.

\section{HYDROGEOCHEMICAL ANALYSIS}

Analyzing and interpreting the chemistry of water (both groundwater and surface water) can provide valuable insights into groundwater-surface water interactions or
Observation also indicates that each type of water is getting mixed with another type of water. Same type of water is found along with upper delta plain and lower delta plain but that type of water was associated with another kind of water which varied according to depth 
and location. Dissolved constituents can be used as environmental tracers to track the movement of water. For example, a particular characteristic of the groundwater chemistry can be used as an indicator of groundwater discharge when measured in the surface water. Such tracers can be used to determine source areas of water and dissolved chemicals in catchments, calculate hydrologic and chemical fluxes between groundwater and surface water; calculate water ages that indicate the length of time water and dissolved chemicals have been present in the catchment (residence times), and determine average rates of chemical reactions that take place during transport (Winter e. al. 1998). Physical factors those affect groundwater chemistry includes residence time and the pathways along which water moves through the system (Fetter 2001).

\section{HYDRO GEOCHEMICAL FACIES ANALYSIS}

Water samples of the study area are divided into two zones: upper delta plain and lower delta plain. Then lower delta plain is divided into western and eastern part and water samples are also described on temporal (dry and wet season) basis. The chemistry of groundwater is controlled entirely by the lithology of the deposits through which the water flows and by the orientation of the flow path within the geologic framework (Back 1966). The ground-water flow pattern is the principal hydrologic control on the chemical character of the water. Within the Coastal Plain sediments, the proportions of clay, glauconitic sand, and calcareous material are the principal lithologic controls over the chemistry of the water (Back 1966). This definition of hydro-chemical facies is a paraphrase of the definition of sedimentary facies given by Moore (1949): "sedimentary facies are a really segregated parts of differing nature belonging to any genetically related body of sedimentary deposits." The term "geochemical facies" has been used by Teodorovich (1949) and Pustalov (1933, 1954) to define different sedimentary environments (Back 1966).

The concept of hydrochemical facies has been used (Seaber 1962, Morgan and Winner 1962 and Back 1960) to denote the diagnostic chemical character of water solutions in hydrologic systems. The facies reflect the effects of chemical processes occurring between the minerals within the lithologic framework and the groundwater. The flow patterns modify the facies and control their distribution.

The term "hydrochemical facies" was used previously by Chebotarev (1955) for a column heading in a table; however, Chebotarev (1955) did not define the term and only it is used to indicate concentration of dissolved solids-that is, low-saline facies, transitionalsaline facies, and high-saline facies.

\section{GROUNDWATER WATER ANALYSIS OF UPPER DELTA PLAIN AND LOWER DELTA PLAIN}

The origin and distribution of different hydro-chemical facies of groundwater in the south-western Bangladesh can be explained by three processes which controls the chemistry of water in the aquifer. These are: (1) recent vertical recharge of aquifer from surface, (2) present and past seawater intrusion and (3) intermediate and deep basin flow (Majumder et. al. 2011)

Recent vertical recharge of aquifer from surface is taking place in both Upper and 
Lower Delta part. In the Upper Delta part fresh water from rainfall and rivers infiltrates into the shallow aquifer. However, in the Lower Delta plain brackish or saline water from tidal surges percolates into the shallow aquifer. Surface water (river water) hydro-chemical facies of Upper Delta part is predominantly $\mathrm{Ca}$ $\mathrm{HCO}_{3}$ type whereas that of Lower Delta part is $\mathrm{Ca}-\mathrm{HCO}_{3}$ and $\mathrm{Na}-\mathrm{Cl}$ type in wet season and mostly $\mathrm{Na}-\mathrm{Cl}$ type in dry season.

Sea water intrusion in the coastal area took place in different times of last 6000 to 10000 years during the delta forming process. From the observation it seems that present day seawater intrusion is taking place mostly in the southern part of Lower Delta plain. In many studies it has been found that the sea level rose to a maximum of about $3.0-3.5 \mathrm{~m}$ relative to present-day sea level during Holocene marine transgression (about 7000 years BP) (Islam and Tooley 1999; Woodroffe and Horton 2005; Shamsudduha and Ashraf Uddin 2007) and encroached most of the Lower Delta plain of the study area. Saline or brackish connate water may also remain in the aquifer.

Intermediate and deep basin flow occurs from north to south direction in the study area (Majumder et. al. 2011). Fresh water flows from the recharge area in the northern part of Bangladesh and flows through the deeper part of the basin and this water flowing towards the Bay of Bengal. From the conceptual model it can be seen that how this basin groundwater flow influences the deep groundwater of upper delta plain and lower delta plain of Ganges delta.

These three mechanisms are the main facts controlling the water chemistry of groundwater. All groundwater data has been plotted on Piper diagram (Fig. 8 \& 9). From the facies table it is clear that the major water type of lower delta plain is $\mathrm{Na}-\mathrm{Cl}$ and $\mathrm{Ca}-$ $\mathrm{Na}-\mathrm{HCO}_{3}$ in shallow groundwater. This water type is also seen in deep groundwater of upper delta plain and lower delta plain.

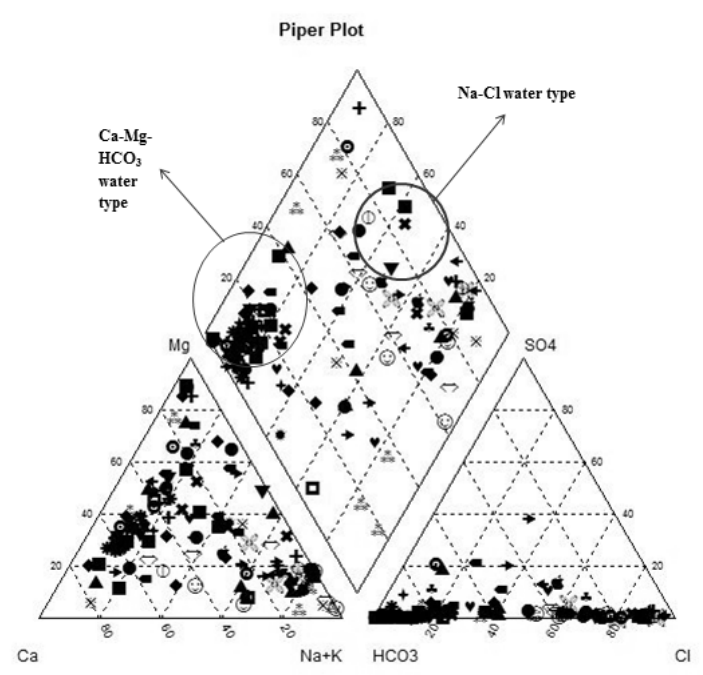

Fig. 8. Piper diagram showing groundwater of upper delta plain. 


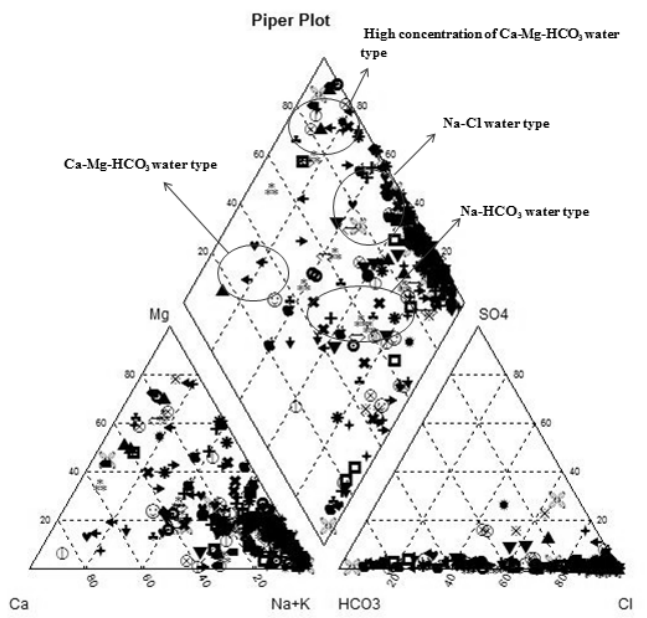

Fig. 9. Piper diagram showing groundwater of lower delta plain.

Water type $\mathrm{Mg}-\mathrm{HCO}_{3}, \mathrm{Na}-\mathrm{HCO}_{3}$ is also found deep aquifer of lower delta plain. In the deep groundwater of upper delta plain, the major water type is $\mathrm{Na}-\mathrm{Cl}$ and $\mathrm{MgHCO}_{3}$. In the deep groundwater of lower delta plain, the major type of water is mixed with $\mathrm{Mg}$ -
$\mathrm{CaHCO}_{3}$ and dominant Na-Cl. Table 1 summarizes the probable origin of groundwater in the different parts of the study area.

Majumder et al. (2011) revealed a complex regional flow of groundwater in the

Table 1. Origin of groundwater interpreted from the major ion chemistry of groundwater

\begin{tabular}{|c|c|c|c|c|}
\hline \multicolumn{2}{|c|}{ Zone } & Aquifer & $\begin{array}{l}\text { Dominant Hydro- } \\
\text { geochemical Facies }\end{array}$ & Probable origin of Water \\
\hline \multirow{2}{*}{\multicolumn{2}{|c|}{ Upper Delta Plain }} & Shallow & $\begin{array}{l}\text { Mixed facies } \\
\mathrm{Mg}-\mathrm{Na}-\mathrm{HCO}_{3} \text { and } \\
\mathrm{Ca}-\mathrm{Mg}-\mathrm{Na}-\mathrm{HCO}_{3}\end{array}$ & $\begin{array}{l}\text { Vertical recharge of aquifer (rainwater) from surface. } \\
\text { Recent water. }\end{array}$ \\
\hline & & Deep & $\begin{array}{l}\text { Mixed facies } \\
\mathrm{Ca}-\mathrm{HCO}_{3} \text { and } \mathrm{Mg}-\mathrm{HCO}_{3} \\
\mathrm{Na}-\mathrm{Cl}\end{array}$ & $\begin{array}{l}\mathrm{Ca}-\mathrm{HCO}_{3} \text { and } \mathrm{Mg}-\mathrm{HCO}_{3} \text { from intermediate basin flow, } \\
\text { Recent water. } \\
\text { Na-Cl from sea water intrusion during Holocene marine } \\
\text { transgression }(3000-7000 \text { cal years BP) }\end{array}$ \\
\hline \multirow{4}{*}{$\begin{array}{l}\text { Lower } \\
\text { Delta } \\
\text { Plain }\end{array}$} & \multirow[t]{2}{*}{$\begin{array}{l}\text { Eastern } \\
\text { Zone }\end{array}$} & Shallow & $\begin{array}{l}\mathrm{Na}-\mathrm{Cl} \\
\mathrm{Ca}-\mathrm{Mg}-\mathrm{Na}-\mathrm{HCO}_{3}\end{array}$ & $\begin{array}{l}\text { Vertical recharge of aquifer from surface (Brackish/Saline } \\
\text { water from river and tidal surge) }\end{array}$ \\
\hline & & Deep & $\begin{array}{l}\mathrm{Na}-\mathrm{Cl} \\
\mathrm{Ca}-\mathrm{Mg}-\mathrm{Na}-\mathrm{Cl} \text { and } \\
\mathrm{Na}-\mathrm{Ca}-\mathrm{HCO}_{3}-\mathrm{Cl} \\
\mathrm{Na}-\mathrm{HCO}_{3} \text { and }\end{array}$ & $\begin{array}{l}\mathrm{Na}-\mathrm{Cl} \text { source could be connate water, or present day sea } \\
\text { water intrusion } \\
\text { Ca-Mg-Na-Cl mixed facies (mixing of sea water with rain } \\
\text { water) } \\
\text { Na-HCO} 3 \text { Old water, deep basin flow from the north }\end{array}$ \\
\hline & \multirow[t]{2}{*}{$\begin{array}{l}\text { Western } \\
\text { Zone }\end{array}$} & Shallow & $\mathrm{Mg}-\mathrm{Cl}$ and $\mathrm{Na}-\mathrm{Cl}$ & $\begin{array}{l}\text { Vertical recharge of aquifer from surface (Brackish / } \\
\text { Saline water from river and tidal surge) }\end{array}$ \\
\hline & & Deep & $\begin{array}{l}\text { Mixed } \mathrm{Mg}-\mathrm{Na}-\mathrm{Cl} \text { and } \\
\mathrm{Mg}-\mathrm{Ca}-\mathrm{HCO}_{3} \\
\mathrm{Na}-\mathrm{Cl}\end{array}$ & $\begin{array}{l}\mathrm{Mg}-\mathrm{Ca}-\mathrm{HCO}_{3} \text { Intermediate basin flow } \\
\mathrm{Na}-\mathrm{Cl} \text { source could be connate water, or present day sea } \\
\text { water intrusion }\end{array}$ \\
\hline
\end{tabular}


Bangladesh using environmental isotope data. The flow is generally from north to south which follows the basement structure and topographic gradient. Three flow systems that can be identified are: shallow flow system which generates from vertical recharge of water from ground surface, a less dominant intermediate flow system, which acts as a transitional zone between the shallow and deep aquifers. This system gets vertical recharge from the shallow flow system and the deep groundwater flow system is restricted to the southern aquifers commencing from the peripheral sites of the study area and it is characterized by long residence time. This concept of Majumdar et. al. (2011) has been visualized and presented in the conceptual models is shown in Fig. 10.
This correlation of water chemistry and basin groundwater flow is pictured in the conceptual model.

\section{RESULTS AND FINDINGS}

From the observation it can be seen that major water type of lower delta plain is Na$\mathrm{Cl}$ and $\mathrm{Ca}-\mathrm{Na}-\mathrm{HCO}_{3}$ in shallow groundwater. This water type is also seen in deep groundwater of upper delta plain and lower delta plain. Water type $\mathrm{Mg}-\mathrm{HCO}_{3}, \mathrm{Na}-\mathrm{HCO}_{3}$ is also found in deep aquifer of lower delta plain. In the deep groundwater of upper delta plain, the major water type is $\mathrm{Na}-\mathrm{Cl}$ and $\mathrm{MgHCO}_{3}$. In the deep groundwater of lower delta plain, the major type of water is mixed with $\mathrm{Mg}-\mathrm{CaHCO}_{3}$ and dominant $\mathrm{Na}-\mathrm{Cl}$.

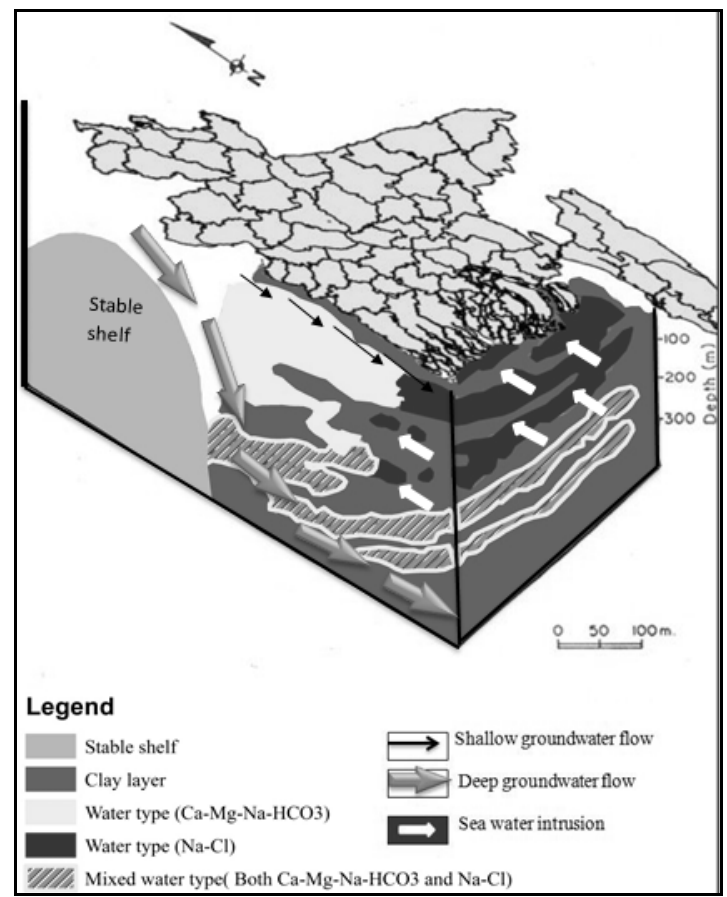

Fig.10. Conceptual flow model showing the water type, groundwater flow direction, water mixing zone and clay layer of south-western Bangladesh. 
The Upper Delta plain lies in the northern side of the study area and is dominated by fluvial processes. Vertical recharge of aquifer from rain or river water flushing through the zone of aeration into the zone of saturation and comprising the shallow groundwater - typically water in the zone is $\mathrm{HCO}_{3}{ }^{-}$rich and is low in TDS. The water types are predominantly $\mathrm{Mg}-\mathrm{Na}-\mathrm{HCO}_{3}$ and $\mathrm{Ca}-\mathrm{Mg}-\mathrm{Na}-\mathrm{HCO}_{3}$.In the Upper Delta part the $\mathrm{Na}-\mathrm{Cl}$ water in deep aquifer probably originated from seawater intrusion during Holocene marine transgression (3000-7000 cal years $\mathrm{BP}$ ). $\mathrm{Ca}-\mathrm{HCO}_{3}$ and $\mathrm{Mg}-\mathrm{HCO}_{3}$ types of water may owe their origin to intermediate or deep basin flow coming from north of Bangladesh. In the Lower Delta part $\mathrm{Na}-\mathrm{Cl}$ type of water predominantly occur in the shallow aquifer.

The origin of this type of water can be attributed to the vertical recharge of aquifer with fresh/ brackish/saline water from numerous rivers or streamlets or from frequent tidal surges. However, occasional $\mathrm{Ca}-\mathrm{HCO}_{3}$ and $\mathrm{Mg}-\mathrm{HCO}_{3}$ type of water may also occur in the eastern part of the Lower Delta plain, which could have originated from the recent recharge of rainwater. The origin of $\mathrm{Na}-\mathrm{Cl}$ type of water in the deep aquifer of Lower Delta part could be connate water or present day seawater intrusion. Fresh water occurring in the deep aquifer in the Lower Delta plain area is mostly of $\mathrm{Mg}$ $\mathrm{Ca}-\mathrm{HCO}_{3}$ and $\mathrm{Na}-\mathrm{HCO}_{3}$ types. This type of water originated from intermediate or deep basin flow from the northern part of Bangladesh. The water of shallow aquifer of Upper Delta plain contains low TDS (Median Dry: 644 mg/l, Median Wet: 588 $\mathrm{mg} / \mathrm{l}$ ) in comparison to the water of deep aquifer (TDS: Median Dry: $816 \mathrm{mg} / \mathrm{l}$, Median Wet: $702 \mathrm{mg} / \mathrm{l})$. In Lower Delta plain the shallow aquifer and deep aquifer have higher TDS water in comparison to Upper Delta plain. This indicates that the shallow and deep aquifer of Lower Delta plain have been subjected to sea water intrusion. The water in the deep aquifer in the coastal area is sometimes called fossil water (Rus 1985) because of its age. The isotopic age of water of deep aquifer (at depths of about $300 \mathrm{~m}$ ) in the Barisal area was dated about 20000 years old (Aggarwal et. al. 2000).

\section{CONCLUSION}

The research work has been carried out to find the relationship between the basin groundwater flow and the current water chemistry of south-western Bangladesh by considering their lithological distribution and aquifer condition. The probable source of deep groundwater is Holocene marine transgression occurred in 3000-7000 cal years BP .Variation of water types clearly indicates that water is mixing with this zone. From the observation of water type it can be said that the groundwater of deep aquifer is clearly influenced by another flow of water and this flow of water is the deep basin flow which is probably coming from north of Bangladesh.

Further study can be done to establish the possibility of this theory. Few attempts can be taken in future for further study in this respect. These may include:

: Bore logs deeper than $350 \mathrm{~m}$ can give accurate information about the subsurface condition. 
: More data can be taken at the northern side of Bangladesh to show the prefect basin flow.

: Isotope data can give reliable information regarding the age and origin of water.

: More water chemistry data for the deeper part of the basin will play an important role to precisely define the origin of water.

Lack of data below $350 \mathrm{~m}$ depth limits the output of this research work. If further depth can be explored in future, clearer picture of groundwater of south-western Bangladesh could be brought to light.

\section{ACKNOWLEDGEMENTS}

The author is grateful to National Science and Technology (NST) Ministry, Bangladesh for providing financial support through awarding a fellowship which helped the author to complete this research work.

\section{REFERENCES}

Aggarwal, P.K., A.R. Basu, R.J. Poreda, K.M. Kulkarni, K. Froehlich, S.A. Tarafder, M. Ali, N. Ahmed, A. Hossain, M. Rahman and S.R. Ahmed. 2000. A Report on Isotope Hydrology of Groundwater in Bangladesh: Implications for Characterization and Mitigation of Arsenic in Groundwater. International Atomic Energy Agency (IAEA), Vienna.

Alam M. 1990. Bangladesh in world regional geology. Columbia University Press, New York.

Back, William. 1960, Origin, of hydrochemical facies of ground water in the Atlantic C'oastal Plain, in Internat. Geol. Cong., Geochemical cycles: Internat. Geol. Cong., 21st Copenhagen 1960, Proc., pt. 1: 87-95.

Back, William. 1966, Hhydrochemical facies and Ground-water Flow Patterns in Northern part of Atlantic C'oastal Plain.
Banerjee, M., and P.K. Sen. 1988.Paleobiology and environment of deposition of Holocene sediments of the Bengal basin, India. The Palaeoenvironment of East Asia from the midTertiary, Proceedings of the 2nd Conference. Centre of Asian Studies, University of Hong Kong, Hong Kong, pp. 703-731.

BWDB, 2013. Hydrogeological Study and Mathematical Modelling to Identify Sites for Installation of Observation Well Nests, Selection of Model Boundary, Supervision of Pumping Test, Slug Test, Assessment of Different Hydrogeological Parameters Collection and Conduct Chemical Analysis of Surface Water and Groundwater. The Climate Change Trust Fund (CCTF) Project Ministry of Environment and Forest.

Chebotarev, I. I. 1955, Metamorphism of natural waters in the crust of weathering: Geochim. etCosmochim. Acta, v. 8, pt. 1, p. 22-48; pt. 2, p. 137-170; pt. 3, p. 19S-212.

Das, D., G. Samanta, B.K. Mandal, T.R. Chowdhury, C.R. Chanda, P.P. Chowdhury, G.K. Basu and D. Chakraborti. 1996. Arsenic in ground water in six districts of West Bengal, India. Environmental Geochemistry and Health 18: 5-15.

Deshmukh, D.S., A.B. Goswami.1973. Geology and groundwater resources of alluvial area West Bengal. Bulletin of Geological Survey of India Series B, No. 34 .

DPHE 2010. Borelog Data Book. Department of Public Health Engineering, Government of Bangladesh. Japan International Cooperation Agency (JICA).

Fetter, C.W. 2001. Applied Hydrogeology (4th ed.), Prentice-Hall, Upper Saddle River, New Jersey.

Goodbred, S.L., S.A. Kuehl. 2000a. Late Quaternary evolution of the GangesBrahmaputra River delta: significance of high sediment discharge and tectonic processes on margin sequence development. Sedimentary Geology 133: 227-248.

Goodbred, S.L. and Y. Saito. 2012. TideDominated Deltas. in: Principles of Tidal Sedimentology (Ed. R.A. Davis, Jr. and R.W. Dalrymple), pp 129, Springer Science + Business Media B.V. 2012.

Islam, M.S. and M.J. Tooley. 1999. Coastal and sea level changes during the Holocene in Bangladesh. Quaternary International 55, 61-75. 
Khan, A. A., Akhtar A. H. and S.M.M Alam. 2000, Evidence of Holocene transgression, dolomitization and the source of arsenic in the Bengal delta. In: Mohamed and Al Hossain (Eds.) Geoengineering in Arid Lands, Balkema, Rotterdam

Khan, S.R. and B. Islam. 2008. Holocene stratigraphy of the lower Ganges-Brahmaputra riverdelta in Bangladesh. Frontiers of Earth Science in China 2: 393-399.

Kuehl, S.A., M.A. Allison, S.L. Goodbred, and H. Kudrass. 2005. The Ganges-Brahmaputra Delta. In: River Deltas - Concepts, Models, and Examples SEPM Special Publication No. 83, SEPM (Society for Sedimentary Geology), ISBN 1-56576-113-8, p. 413-434.

Majumder, R.K. M. A. Halim, B. B. Saha, Reo Ikawa, Toshio Nakamura, Makoto Kagabu \& Jun Shimada. 2011, Groundwater flow system in Bengal Delta, Bangladesh revealed by environmental isotopes Environ Earth Sci (2011) 64:1343-1352

Moore, R. C. 1949, Meaning of facies : Geol. Soc. Mem.39, 34p.

Morgan, J.P., and W.G. McIntire.1959. Quaternary Geology of the Bengal Basin, East Pakistan and India; Geological Society of America, Bull. 70: 319-320.

Morgan, C. O. and M. D. Winner Jr. 1962. Hydrochemical facies in the "400-foot" and"600foot" sands of the Baton Rouge area, Louisiana, in Short papers in geology hydrology, and topography: U.S. Geol. Survey Prof. Paper 450B, p. B120-B121.149:133-154.

Pustovalov, L. V., 1933. Geochemical facies and their meaning in general and economical geology, in Problems Geology U.S.S.R.: 1(1): 57-80.

Rus, J.S. 1985. Geohydrological Investigations in Khulna.DPHE Water Supply and Sanitation Projects.DPHE.Netherlands-Bangladesh Development Co-operation Programme.
Seaber, P. R. 1962. Cationhydrochemical facies of groundwater in the Englishtown Formation, New Jersey, in Short Papers in geology, hydrology, and topography: U.S. Geol Survey Prof. Paper 450-B, p.B124-B126.

Shamsudduha, M. and U. Ashraf. 2007. Quaternary shoreline shifting and hydrogeologic influence on the distribution of groundwater arsenic in aquifers of the Bengal Basin.of Asian Earth Sciences 31 (2007) 177194. www.elsevier.com/locate/jaes

Teodorovich, G. I., 1949, Siderite geochemical facies of seas and saline waters in general as oil-producing: Doklady Akad. Nauk SSSR, 69(2): 227-230 (see rev. by Chilingar, G. V.). (Also in Am. Assoc. Petroleum Geologists Bull., 39(5): 762-770.)

Umitsu, M. 1987. Late Quaternary sedimentary envrionment and landform evolution in the Bengal lowland. Geographical Review of Japan 60: 164-178.

Umitsu, M. 1985. Natural levees and landform evolutions in the Bengal Lowland, Geographical Review of Japan 58: 149-164.

Umitsu, M., 1993. Late Quaternary sedimentary environments and landforms in the Ganges delta. Sedimentary Geology 83:177-186.

Wright, L.D. 1985. River deltas. In: Coastal Sedimentary Environments (Ed. A.R. Davis), pp. 1-76. Springer-Verlag, New York.

Winter, T.C., J. W. Harvey, O.L. Franke and W.M. Alley. 1998. Ground water and surface water: A single resource. USGS Circular 1139.

Woodroffe, S.A. and B.P. Horton. 2005. Holocene sea level changes in the Indo-Pacific. Journal of Asian Earth Sciences 25(1): 29-43.

http://en.wikipedia.org/wiki

https://en.wikipedia.org/wiki/Brahmaputra_River

(Received revised manuscript on 18 March, 2018) 